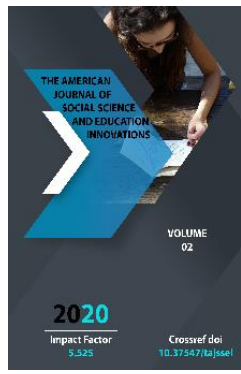

\title{
Soviet Religious Policy In Turkestan
}

\author{
Salmonov Ahmadjon Muqaddasovich \\ Candidate Of Historical Sciences, Associate Professor At The Fergana State University, \\ Uzbekistan
}

Copyright: Original content from this work may be used under the terms of the creative commons attributes 4.0 licence.

\section{ABSTRACT}

This article describes the Soviet government's religious policy in Turkestan. Based on an analysis of archival documents and other sources, the author scientifically substantiates the Soviet government's religious policy in Turkestan.

\section{KEYWORDS}

Charitable Fund, Generation Fund, Council of People's Commissars, Executive Committee of Turkestan, Mufti, Sa'id, Hujja, Alam, Pir, Mutawalli, Eshon, Sheikh, Sufi, Mosque, Madrasa, Khori-khana, Khanaqah, Qur'an, Fiqh, Sharia courts , Jami Mosque, Uthman Qur'an, Land and Water Reforms, county, Imamate.

\section{INTRODUCTION}

Throughout the millennia, starting in the Middle Ages, Islam and its role have played an important role in the social, cultural, educational and economic life of the region in which we live. In the second half of the 19th century and at the beginning of the 2oth century, when historical processes were very acute, most of the land and property in the Bukhara Emirate, the Khanate of Kokand as well as the Khanate of Khiva belonged to religious institutions and organizations. Religious groups such as Mufti, Sa'id, Hujja, Alam, Pir, Mutawalli, Eshon, Sheikh and Sufi were also major owners. Until 1917, the number 
of religious figures and scholars who worked in Muslim institutions and organizations in Turkestan, such as Madrasa, Khori-khana, Khanaqah, was also large. At the beginning of 2oth century on the territory of the GovernorGeneral of Turkestan there were 268 madrassahs [1.4,7], 1498 large and 11,230 small mosques. Furthermore, the number of imams who served in them was 12,499 [2.564-565]. In Fergana region there are also 236 sanctuaries [3.566].

"There were 360 mosques, 140 madrasas, 360 primary religious schools and other buildings in Bukhara in the early of 12th century" [4.16]. Their material supply was provided by the fund's lands and the property of several hundred thousand tanabs.

At the same time in the Khanate of Khiva there were 120 madrasas, 73 cemeteries and 71 holy places. The Islamic faith was rooted in national customs and traditions, and the management of public order based on the Qur'an, hadith and Islamic jurisprudence became one of the sources of spirituality [5.8-9], [6.79-81].

On November 2, 1917 was published the "Declaration of the Rights of Peoples of Russia"" At the same year of November 20 was declared "Appeal to all Muslim workers of Russia and the East". It officially proclaimed that the equality of all citizens as well as the right of different nations to separate from the Russian Federation. Moreover, it was considered the abolition of national, religious privileges and restrictions.

In the first years of the Soviet power, the Turkestan People's Commissariat of Education issued order No. 6486 on December 14 of 1918. On this basis, financing of Muslim schools was stopped as well as the waqf's property was confiscated [7.26].

\section{LITERATURE REVIEW}

The use of the waqf property in Turkestan, which had long been the material basis of education, culture and was managed by trustees, was suspended (from 1918 to 1920 the waqf property was included into the budgets of the state and local organizations, madrasas, sanctuaries were closed. Sharia courts were abolished). The policy of confiscation at the expense of the state also had a significant negative impact on religious institutions and organizations. Islamic institutions found themselves in an economically, politically and ideologically disadvantageous position after depriving them of state benefits and confiscating property under their control. Thus, religious leaders protested against the Soviet government, demanding the return of land, caravanserais, trade racks, craft workshops, Khanaqah and mosques, which were mainly owned by the waqf.

In 1918-1919 the local Executive Committees of the Soviet government organized a campaign to replace the trustees of the Fund's property with people of their own choosing, accusing most of the trustees of embezzling the Fund's income. On July 19, 1919, the Council of Deputies of Old Margilan fired the imam of the "Yorotalik" Mosque as well as the trustee of the "Okulboy" madrassa for embezzling the Fund's income for personal gain. [8.150]

On August 27, 1918, at the meeting of the Namangan city executive committee, the trustee of the "Ayritom" mosque Ismailkhoja Eshan was dismissed for giving false information about his "crimes," i.e. the income and expenses of the mosque [9.6-10].

At the same year, the trustee of Kholkhoja madrassa Eshan Mullah Abdukahor, the trustee of Abduvahoboy madrassah Mullah 
Ashur Rakhimov and the imam of Sobirkhoja mosque in Shahrixon Mullah Sadullakhoja were fired for looting [10.20, 22, 25, 30, 48].

According to archival sources, in 1918-1921 most madrasas and mosques in Samarkand, Ferghana and Syr-Darya regions were destroyed, leaving them without sources of income.

Enlightened representatives of the Turkestan Republic as well as the Jadid movement in 19191920 expressed firm views on the restoration of funds and their transformation into the material base of religious institutions and organizations. On June 30 of 1920, at the Congress of the heads of public education of the Turkestan ASSR, Munawwar Qari Abdurrashidkha ogli (1878-1929) highlighted about the funds in Turkestan: "The funds are needed not only for religious and charitable, but also for the development of culture and public education. The fact that national schools and madrasas are the material source of our science and art, which provides general information, deprives them of a purely religious point of view," [11.118-119].

On June 20, 1922 was adopted the Decree No. 75. This document provides for the return of the waqf lands in three regions of the Turkestan Republic (Samarkand, Fergana, and Syr-Darya) to religious institutions such as stores, caravanserais, warehouses, parks, repair of madrassahs and mosque buildings, as well as the use of personnel and workers. In addition, it was decided to open schools under these institutions. [12.55].

According to the state decree, religious institutions operate in accordance with Soviet land use legislation. Furthermore, the income of mosques from their funds was entirely owned by the mosques. Each counties had a madrasa and waqf governing body. The board consisted of a total of 6 members, including two mudarris, one judge and teachers. These councils were formed in Kokand, Andijan, Old Margilan, Namangan, Samarkand and Khujand [13.55-56].

\section{ANALYSIS AND RESULTS}

The madrasah boards in more than forty districts were subordinated to regional boards, and their administration was located in Tashkent, the capital of Syr Darya Province. In districts where the number of madrasahs did not exceed 20, pedagogical councils, people's judges and people's teachers were formed. These councils existed in cities as Osh, Kattakurgan, and Jizzakh.

It was also given clear instructions on the management of religious institutions and madrassas. The task was assigned to the madrassa council. The council, along with all the teachers and trustees, elected the headmaster of the primary school and 2 senior mullahs [14.56].

An economic commission was established at the madrassah council, which included a senior teacher, a trustee, and a student (mullah) elected from among the students. The threemember commission was tasked with renting out agricultural land, stores, warehouses, caravanserais, and baths, selling crops, and repairing madrasah buildings, rooms for mullahs and maids, and classrooms. The Economic Council was also responsible for preparing cost estimates for the school year [15.57-58].

To repair madrasas and mosques, organize religious rituals, events, and religious education, it was first necessary to receive income from the ownership of the waqf, which 
was their material base. In the five years since the Bolsheviks came to power, dozens of madrasas and thousands of mosques had to be repaired by transferring state funds to religious institutions and organizations.

Nevertheless, the fund's assets were returned to religious institutions and organizations, the duties of the trustee in its use were also determined by special decree. The trustee is elected by the madrassah council in a general vote, must be at least 30 years old, and is approved by the commission of the district executive committee. In addition, in prestigious madrassahs was appointed an assistant mudarris. The duties of the trustee include keeping a book of income and expenses, drawing up a cash report, collection and storage of funds, the allocation of funds for construction and timely payment of state taxes, the rental of property by decision of the madrassah council [16.58-59].

\section{CONCLUSION/RECOMMENDATIONS}

The Soviet government's policy toward religious institutions and organizations in Turkestan in 1917-1924 was based on the principles of instability and mistrust. All measures were aimed at strengthening the Bolshevik order and the foundations of the Soviet regime in the country.

The opening of religion and religious institutions in 1922-24 was due to measures taken by the Soviet government during the New Economic Policy (NEP). Factors such as the complete destruction of the economy as a result of ongoing military conflicts, terrible famine and the process of resistance to the Bolshevik order forced the government to act amicably.
Overall, the development of education and culture in Turkestan, as well as the economic situation associated with religious institutions, also led the Soviet authorities to fear a policy of temporary open atheism.

According to the decision of the Central Executive Committee of the Turkestan ASSR, it was planned to establish control over the founding institutions and the religious department of the Mahkama-yi Sharia, by the education department, exacerbated the situation of religious institutions. Oldfashioned schools and cafeterias were reformed by the department of education.

\section{REFERENCES}

1. TsGA RUz. F.-47. D-116. L-2.

2. TsGA RUz. F.-1. D-29. L-18.

3. TsGA RUz. F.-1. D-29. L-18.

4. Ergashev B. X. Ideology natsionalnoosvoboditelnogo dvijenie $v$ Buxarskom emirate. -T .: Fan, 1991

5. Matkarimov M. State structure, supervisors and economy of the Khorezm Republic. Urgench, 1993.

6. Valievich, Y. S. (2020). CHILDREN'S GAMES AS AN IMPORTANT FACTOR IN THE UPBRINGING OF A HARMONIOUS GENERATION. European Journal of Research and Reflection in Educational Sciences Vol, 8(9).

7. Mirzarahimov, B. (2019). The factor of good neighborhood and tourism development (Philosophical analysis). Scientific Bulletin of Namangan State University, 1(1), 140-145.

8. Mirzarahimov, B. H. (2020). The Tasks Of Tourism In Aesthetic Education: The Harmony Of Historicity And Modernity. The American Journal of Social Science 
and Education Innovations,2(09), 652-

658.

9. Yuldashev S. Restoration of national values. // Society and management.

Tashkent. 2002. № 4.

10. TsGA RUz. F.- 34. D-34. L-1.

11. FerRGA. F.- 121. D-31. L-1.

12. FerRGA. F.-121. D-31. L-1.

13. FerRGA. F.- 121. D-31. L-1.

14. TsGA RUz. F.- 94. D-320. L-1.

15. TsGA RUz. F.- 25. D-1414. L-1.

16. TsGA RUz. F.- 25. D-1414. L-1.

17. TsGA RUz. F.- 25. D-1414. L-1.

18. TsGA RUz. F.- 25. D-1414. L-1.

19. TsGA RUz. F.- 25. D-1414. L-1. 